however, the provisions of the law, as stated above, apply only to the lower posts in the service, except as regards representation allowances. The positions of minister and ambassador lie outside the scope of the law. It is true that the Secretary of State is required to report to the President the names of secretaries, counselors and others who have demonstrated special capacity, for promotion to the grade of minister, but naturally there is no assurance that they will be promoted. Whether they will or not depends on the President. It is to be hoped that our Presidents in the future will see the advantage not only of promoting specially qualified experienced secretaries to ministerial posts, but also of rewarding competent ministers by advancing them to ambassadorships.

J. W. Garner.

\title{
NATIONAL SECURITY AND INTERNATIONAL ARBITRATION
}

The most significant feature of the development of international arbitration during the past generation has been the gradual widening of the field of controversies to which the obligation to arbitrate should apply. The plan of a comprehensive agreement to arbitrate all disputes without restriction seemed at the time of the First Hague Conference the ideal of a fardistant millennium, and to many, indeed, not even an ideal, but an unwarranted restraint upon national progress. At the moment of present writing (September 17) the plan seems to have come within the range of practical possibilities and the Assembly of the League of Nations is discussing ways and means of giving it definite actuality.

So long as agreements to arbitrate were concluded only in the presence of a concrete dispute which diplomacy had failed to settle, no question was raised as to the nature of the national interests involved in the dispute. A boundary controversy could be arbitrated if the parties saw fit to do so, and the vital or non-vital character of the interests at issue did not figure in the agreement. Nor was there any question as to the "justiciability" of the matter under dispute. Any matter was justiciable when the parties had agreed to settle it by arbitration and had determined the principles to be applied by the arbitrators.

It was only when nations began to conclude the so-called "general treaties of arbitration," looking to the arbitration of future disputes, that the question arose as to the character of the cases that it might be feasible to agree in advance to arbitrate. Quite clearly, in a community of nations organized as it then was and advocating the principles which it then advocated, it would not do for a state to commit its most important interests to the keeping of a tribunal not under its direct control. When the proposal of a general treaty of arbitration was made at the First and again at the Second Hague Conference there was no thnight that the obligation to 
arbitrate should extend to more than a definitely limited group of cases. It will be remembered that the list of arbitrable matters voted upon by the First Commission of the Conference of 1907 related to interests of a. negligible character, and that the advocates of compulsory arbitration welcomed the list only as evidence of the acceptance of a general principle. The opposition of Germany and Austria-Hungary defeated even this first step, and the conference was obliged to content itself with the famous voeu admitting "the principle of compulsory arbitration" and recommending that certain disputes, in particular those relating to the interpretation of treaties, might be submitted to compulsory arbitration without restriction.

Failing the conclusion of a general arbitration treaty at The Hague, the individual Powers resorted to separate treaties between themselves, following the example of the South American states during the last quarter of the nineteenth century. With but few exceptions these agreements all fell short of an absolute obligation. The Root treaties of 1908, after the model of the Anglo-French treaty of 1903, embraced questions of a legal nature or questions relating to the interpretation of treaties, but made exception of matters affecting the vital interests and the honor of the contracting parties. The proposed Taft treaties widened the field considerably by including differences "justiciable in their nature by reason of being susceptible of decision by the application of the principles of law or equity," leaving nonjusticiable matters outside the obligation.

With the establishment of the League of Nations and the appointment, in pursuance of Article 14 of the Covenant, of a committee to formulate a plan for the Permanent Court of International Justice, the old question arose as to the cases to which the obligation to arbitrate should extend. The Advisory Committee of Jurists drafted a plan in which the court was given jurisdiction over four groups of legal questions; but this proposal was rejected by the Assembly of the League, and in place of it an article was adopted limiting the jurisdiction of the court to the cases which might voluntarily be submitted to it. Provision was, however, made that individual states might accept the jurisdiction of the court as obligatory in respect to the four specified classes of cases. While the optional clause has been signed by a number of the smaller Powers, even in regard to them there still remain excluded from the obligation assumed any questions which might be regarded as "political."

What is at the root of the unwillingness of the leading states to pledge themselves to arbitrate all future disputes without exception? What are the "vital interests" which they feel it would be unwise to submit to the judgment of an arbitral tribunal or of a permanent court? The answers to these two questions will put to the test all the projects to "outlaw war" which have been so widely discussed of recent months. For it is clear that the conditions which have led states to provide a loop-hole of escape from the obligation to arbitrate are also the conditions which keep them from 
renouncing altogether the right to make war should a particular emergency arise. The whole history of modern arbitration has been the history of attempts to outlaw war by narrowing the field within which it could be resorted to. Progress has been made by gradual elimination of the cases which appeared to involve the least sacrifice of national interests. The last step, the absolute outlawry of war, arbitration without exceptions of any kind, is the most difficult of all, in that it involves a new organization of international society and doubtless new principles of international relationships.

Foremost among the interests which states are intent upon safeguarding is obviously the protection of their national existence. To that end all foreign policies are primarily directed and whatever bears upon it, even remotely, assumes a gravity beyond its immediate importance. The case has been the same whether the component elements of the state have been homogeneous or heterogeneous in respect to national aspirations. Under the old order in existence in 1914 the protection of its national existence was left to each state and the community at large assumed no responsibility for the maintenance of peace. Under such circumstances no state could be expected to agree to turn over to an arbitral tribunal, however impartial its composition, a controversy in which matters bearing upon its self-preservation might be in any way involved. The United States, for example, regarding the Monroe Doctrine as bearing upon its national security, would have unhesitatingly rejected any suggestion of arbitration if an adverse decision of the tribunal might have the effect of weakening that barrier against attack.

But the right of national existence, in a community lacking any principle of collective responsibility and having no agencies for the maintenance of peace, became a very complex right, with ramifications extending into many aspects of national life. The size of, a state's armaments for self-protection was a matter which the state could not permit to be questioned before an international tribunal, although it might appear to a neighboring state that armaments maintained for alleged self-defense had an aggressive character. Thus Germany would have promptly rejected in 1911 any suggestion of arbitrating the question whether the growing size of her fleet constituted a menace to Great Britain. Again, cases could occur in which the conditions of government in one state constituted a nuisance to another state and thereby affected its national peace. Thus the United States would have been unwilling to commit itself in advance to accept the decision of an arbitral tribunal on the point of determining whether the time had come to put an end to the nuisance of misgovernment in Cuba. Thus, also, Austria-Hungary rejected the suggestion of mediation in the exercise of its right to call Serbia to forcible account for the agitation which was being carried on in that country against the integrity of its legal dominions.

Moreover, the defense or conservation of national existence has been 
intimately tied up with the extension of national commerce and the development of national industry. Here the problem assumes, doubtless, its most difficult form. In a community of nations organized (or unorganized!) on the basis of individual self-help the development of the economic life of the state is intimately connected with the power of the state to defend itself against attack. Material prosperity thus becomes, in the case of the leading Powers, a condition of national independence. But the material prosperity of the modern industrial state requires the possession of the necessary raw materials as well as markets for the sale of manufactured products, both of which extend the problem of national self-preservation far beyond the boundaries of the country. Thus Germany and France would have been unwilling to commit themselves in advance to arbitrate such a question as their relation to Morocco, each believing that the objects involved in the dispute, control over the mineral and other resources of the country, had a vital bearing upon their industrial welfare. Nor would Great Britain have considered for a moment the acceptance in advance of an obligation to arbitrate such a question as the demand of Germany for a "place in the sun," if the decision of the court were to infringe in any way upon Britain's control over her colonies.

How far would the assumption, such as is now being discussed at Geneva, by the nations as a body of a collective responsibility for the maintenance of peace and the establishment of agencies for its effective administration remove the chief obstacles to a general agreement of obligatory arbitration? The question cannot be answered with finality. Undoubtedly, if the leading states could be convinced that adequate protection for their national independence could be secured to them by an international guarantee of the League of Nations, they would be the more readily inclined to submit many questions to arbitration which in the past have been regarded as excluded under the caption of "vital national interests." Many of the smaller states have already come to believe that their best protection rests in the resort to arbitration rather than to the decision of arms, and their signature of the optional clause of the statute of the Permanent Court would indicate a willingness to go even further towards closing the loop-holes in their obligation to arbitrate. There still remains the obstacle that the Great Powers and a number of the smaller ones have interests which cannot be included under the heading of national security, in the sense of the proposed guarantee of the League of Nations, and yet which they consider too vital to leave to the decision of an international tribunal.

Justice is, after all is said, an essential condition of the adoption or permanence of an adequate system of law, and it is clear that under the complex conditions of international life which have developed out of the aggressive nationalism of the past there are many cases where the existence of injustice must make it hard for a state to bind itself to accept the status quo as a permanent condition of things. Perhaps the experience of the alternative 
of war may help to restrain some hands. More hopeful, however, is the promise that the Assembly of the League of Nations may prove to be a public forum for the expression of alleged national wrongs and bring the power of public opinion to right grievances which have only a moral, not a legal basis. To speak in familiar terms, statute law must remedy the defects of the common law. It will be observed that the Covenant of the League of Nations leaves it optional to a state to resort to the regular procedure of arbitration or to bring its case before the Council or the Assembly of the League. Doubtless the latter procedure will be followed in cases where these political, as distinct from legal, questions are at issue. But it would lead us too far afield to speculate how far the League may in time undertake to right individual wrongs by the adoption of general international conventions. Sufficient for the day is the problem in hand. Security comes first; then other aspects of justice.

A like answer is to be given to the question whether certain matters, such as the regulation of national commerce or the exclusion of alien immigrants, which are now regarded by international law as "domestic questions," but which actually do cause friction between nations, may not in time be brought under the control of a general rule of law. At present, if a case involving such matters were to be presented to the Permanent Court, it could only dismiss the suit with the statement that the defendant could not be disturbed in the performance of a clearly legal act because of its injurious effect upon another state. There is, therefore, no need of a reservation of "domestic questions" from the jurisdiction of the Permanent Court or of the League. It is sufficient that certain questions be understood to be domestic ones, and the matter is settled. A future generation may be left to determine whether what has been a domestic question in the past may not henceforth be an international one.

C. G. Fenwick.

\section{EXTRATERRITORIALITY IN CHINA}

The present issue of the Journal contains two enlightening articles dealing with the question of the abolition of extraterritoriality in China, ${ }^{1}$ written respectively from the American and the Chinese viewpoint.

It is interesting and encouraging to note the general similarity of the approach of the two authors to their subject. Whatever their differences as to the causes and history of extraterritoriality, they are in agreement not only in holding that it is an unfortunate anomaly which ought to be abolished, but that it can be abolished in a manner which will conserve the rights of all concerned and benefit both the foreigner and the Chinese.

${ }_{1}$ "Extraterritoriality in China," by Charles Denby, supra, pp. 667-675; "Foreign Jưrisdiction in China," by N. Wing Mah, supra, pp. 676-695. 